\title{
The Flight of a Flock of Common Eiders, Somateria mollisima, in Northumberland Strait Interrupted by the Confederation Bridge, New Brunswick-Prince Edward Island
}

\author{
Colin M. MacKinnon ${ }^{1}$, Andrew C. Kennedy, and Matthew L. Horsman
}

Environment Canada, Canadian Wildlife Service, Atlantic Region, P. O. Box 6227, Sackville, New Brunswick E4L 1G6 Canada

${ }^{1}$ Corresponding author; email: colin.mackinnon@ec.gc.ca

MacKinnon, Colin M., Andrew C. Kennedy, and Matthew L. Horsman. 2013. Flight of a flock of Common Eiders, Somateria mollisima, in Northumberland Strait interrupted by the Confederation Bridge, New Brunswick-Prince Edward Island. Canadian Field-Naturalist 127(2): 175-177.

An observation of the flight of a flock of Common Eiders, Somateria mollisima, on 24 October 2012 suggests that, 15 years after construction of the Confederation Bridge connecting New Brunswick and Prince Edward Island (12.9 km in length over the Northumberland Strait), the bridge may still be a partial barrier to bird flight and possibly migration. Although we believe the Common Eiders we observed intended to fly over or under the bridge, none of the 44 Common Eiders crossed the structure during the observation period.

Key Words: Common Eider; Somateria mollisima; Black Scoter; Melanitta americana; seaducks; migration; Confederation Bridge; Northumberland Strait; Cape Jourimain National Wildlife Area; New Brunswick; Prince Edward Island

Construction of the Confederation Bridge was completed in 1997, and it has been in operation for 15 years. The $12.9 \mathrm{~km}$ long structure spans the Northumberland Strait at its narrowest point, between Cape Jourimain National Wildlife Area, New Brunswick, and Borden, Prince Edward Island (Figure 1). The Confederation Bridge utilizes a multi-span concrete box girder structure and is composed of three main components: the approaches (east and west), a deck $40 \mathrm{~m}$ high, and a ship navigation span $60 \mathrm{~m}$ high. The east approach is $0.6 \mathrm{~km}$ over 7 piers and the west approach is $1.3 \mathrm{~km}$ over 14 piers. The main bridge is $11.0 \mathrm{~km}$ (44 piers) in length, with the elevated navigation section $2.50 \mathrm{~km}$ in length in the middle. The typical span between piers is $250 \mathrm{~m}$.

As part of collecting pre-construction baseline data in 1990 and as part of the environmental assessment process for the proposed bridge, MacKinnon et al. (1991) monitored seabird and seaduck movement through the Northumberland Strait. Twenty-two hours of surveys, during spring and fall, produced 5214 observations of 25 species. Of these, 641 (12.3\%) were Common Eiders, Somateria mollisima (MacKinnon et al. 1991).

During the early 1990s, concerns were expressed about the possible effects that the Confederation Bridge might have on seabird migration; such as being a barrier to flight. The closest comparable structure at that time was the Canso Causeway, which connects Cape Breton Island with mainland Nova Scotia. Erskine and Smith (1986) reported that, although the causeway was a comparatively low and short structure, it was believed to be a barrier to flight for Common Eiders.

In 1997, Hicklin and Bunker-Popma (2001) conducted surveys at the Confederation Bridge during the spring migration, similar to those reported by Mac-

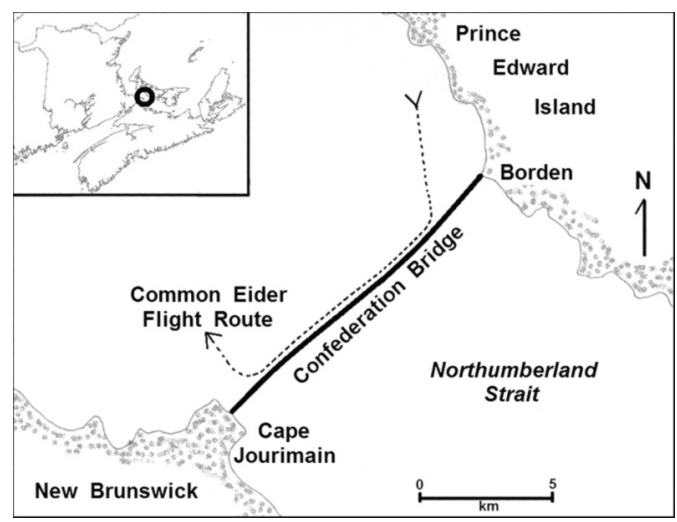

Figure 1. Orientation of the Confederation Bridge, connecting New Brunswick with Prince Edward Island, and the route of the Common Eider, Somateria mollissima, flock observed on 24 October 2012.

Kinnon et al. (1991). The Confederation Bridge was then in operation, and comparison with observations of MacKinnon et al. (1991) suggested that it formed a partial barrier to scoter (Melanitta spp.) migration. MacKinnon and Kennedy (2006) reported such an occurrence. On 13 April 2006, a flock of 18 Black Scoters, Melanitta americana (formerly M. nigra), repeatedly tried to cross over the bridge with only partial success; only 3 birds (17\%) crossed over during the observation period.

No comparable observations have been reported concerning Common Eiders. It is recognized, however, that Common Eiders generally avoid flying over land (Gauthier et al. 1976) and, when they do, have been known 
to collide with anthropegenic structures (MacKinnon and Kennedy 2011). It is also important to note that recent studies of flight altitudes of some species of migrating seaducks show that, under certain conditions, seaducks may fly high enough to avoid some anthropogenic obstacles (Kahlert et al. 2012).

At noon (1200) on 24 October 2012, we observed a flock of Common Eiders as we were travelling across the Confederation Bridge from Prince Edward Island to New Brunswick by vehicle $\left(46^{\circ} 12^{\prime} \mathrm{N}, 63^{\circ} 45^{\prime} \mathrm{W}\right)$. At the time of the observation, visibility was excellent with $95 \%$ high cloud cover, temperature of $15^{\circ} \mathrm{C}$, and light winds from the northwest.

Shortly after we entered the Confederation Bridge from Borden, Prince Edward Island, at 1150, we observed the flock of Common Eiders (divided into two groups of 25 and 19 birds separated by $>100 \mathrm{~m}$ ) approaching the bridge at an oblique angle from the north. The flock was possibly on its southward migration (this species does not breed in the Northumberland Strait and winters in only small numbers (Boyer 1972; Lock 1986; Erskine 1987; Goudie et al. 2000).
The birds were first sighted about $1 \mathrm{~km}$ west of the coastline of Prince Edward Island (Figure 1). As they approached the bridge, the two sets of birds turned to the southwest and proceeded to fly parallel with, and approximately $75-100 \mathrm{~m}$ north of, the Confederation Bridge at a height of $<10 \mathrm{~m}$ above the water. The two groups of birds, now separated by $<75 \mathrm{~m}$, remained at a more or less constant speed, and we observed them continue on an essentially straight southwesterly direction parallel to the course of the bridge for approximately $10.6 \mathrm{~km}$. Although some of the birds were occasionally lost from sight for brief periods ( $<25$ seconds), at no time did the birds appear to attempt to fly over or underneath the bridge.

Once the birds had passed the elevated navigation channel situated in the middle of the Northumberland Strait, the two groups of birds merged (Figure 2). Near the New Brunswick coastline, at a point $1350 \mathrm{~m}$ from shore where the level deck of the bridge ( $40 \mathrm{~m}$ above the water) starts to slope down towards the bridge abutment, the speed of the flock decreased noticeably. At this point, the flock dispersed slightly. It started to gain

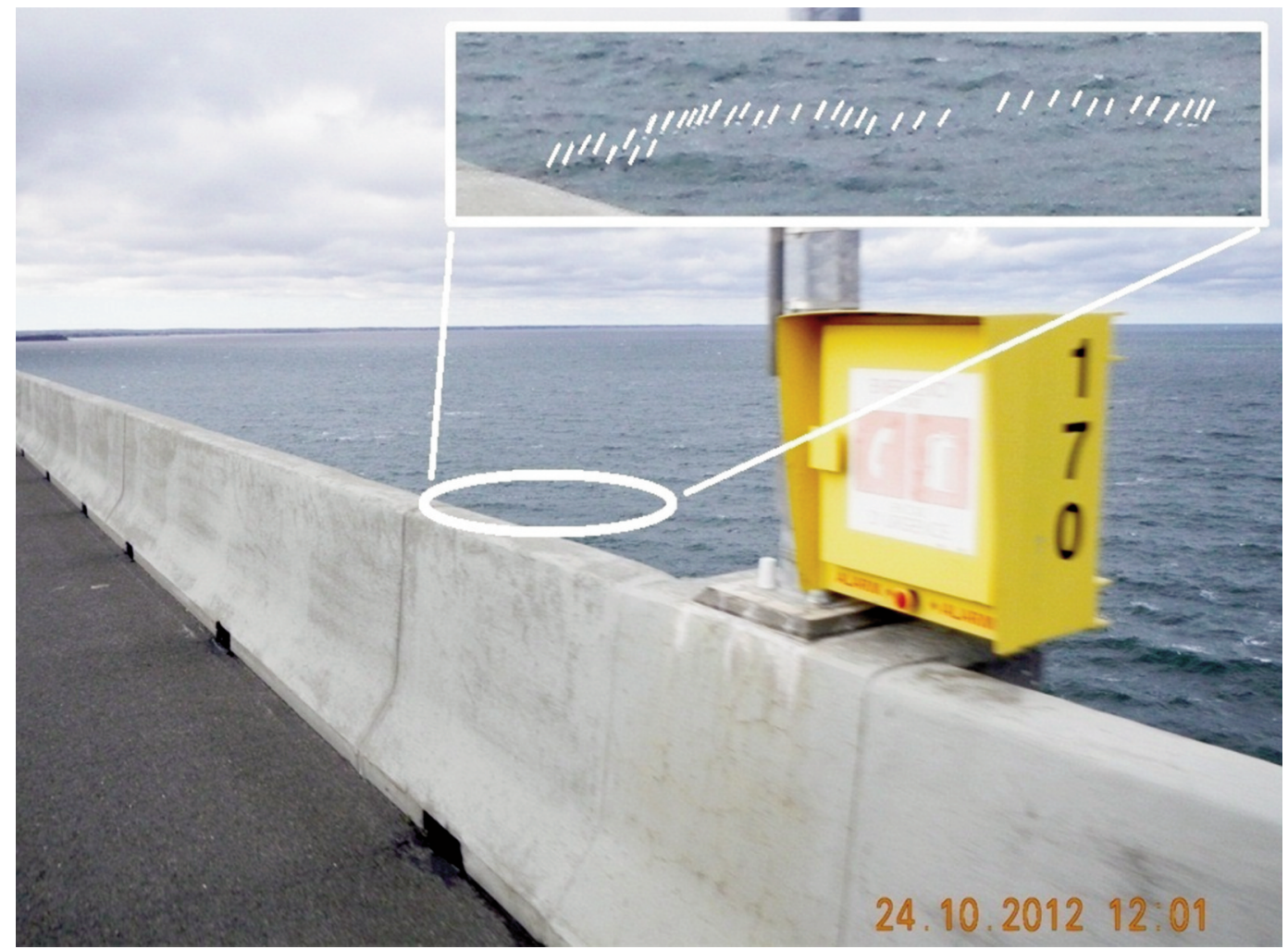

Figure 2. Flock of Common Eiders, Somateria mollisima, flying parallel to the Confederation Bridge (birds indicated by tick marks in inset) on 24 October 2012. Photograph location $46^{\circ} 11^{\prime} 49.2^{\prime \prime} \mathrm{N}, 63^{\circ} 46^{\prime} 15.8^{\prime \prime} \mathrm{W}, 5 \mathrm{~km}$ from the Cape Jourimain (New Brunswick) headland, located at the middle left of the photograph. The bridge deck is $40 \mathrm{~m}$ above the water. Photo: C. MacKinnon. 
altitude but remained below the level of the bridge deck. The flock quickly regrouped, dropped altitude to the original $<10 \mathrm{~m}$ above sea level, and changed course to a more northwesterly direction heading away from the bridge.

The flock was last seen at 1205 continuing over the water in a northward direction approximately $1 \mathrm{~km}$ east of the Cape Jourimain (New Brunswick) headland (Figure 1), having never crossed over or under the bridge.

The velocity of the vehicle in which we were driving during the observation period ranged from 62 to $80 \mathrm{~km} /$ hour, with an average rate of $75 \mathrm{~km} /$ hour. Throughout the crossing, the Common Eiders were either parallel to or just slightly ahead of the observers. Observations ceased at 1205. It is noteworthy that the Confederation Bridge is built in a gentle " $\mathrm{S}$ " curve; thus the flight of the Common Eider flock clearly followed the contours of the bridge and did not go in a straight line across the Northumberland Strait.

This observation demonstrates that 15 years after construction, the Confederation Bridge may be perceived by Common Eiders as a partial barrier to flight as well as possibly to their southward migration through the Northumberland Strait in the fall. More detailed observations are required to ascertain how significant a deterrent the bridge is to eider spring or fall migration. This note may also assist in decision making for other comparable mega-structures in the marine environment.

Concerns similar to those raised in the early 1990s about the Confederation Bridge are now being expressed regarding the possible impacts on seabird movement of a proposed bridge across the Suur Väin Strait in western Estonia, recognized as a significant waterbird migration route in northern Europe (Kahlert et al. 2012).

\section{Acknowledgements}

We thank Paul Chamberland, Sheri FaulknerJackson, and Peter Hicklin for helpful reviews of the manuscript.

\section{Literature Cited}

Boyer, G. F. 1972. Birds of the Nova Scotia-New Brunswick border region. Second edition. Canadian Wildlife Service Occasional Paper No. 8. Canadian Wildlife Service, Environment Canada, Ottawa, Ontario. 47 pages.
Erskine, A. J. Editor. 1987. Waterfowl breeding population surveys, Atlantic Provinces. Canadian Wildlife Service Occasional Paper No. 60. Canadian Wildlife Service, Environment Canada, Ottawa, Ontario. 82 pages.

Erskine, A. J., and A. D. Smith. 1986. Status and movements of Common Eiders in the Maritime Provinces. Pages 20-29 in Eider Ducks in Canada. Edited by A. Reed. Canadian Wildlife Service Report Series No. 47. Canadian Wildlife Service, Environment Canada, Ottawa, Ontario. 177 pages.

Gauthier, J., J. Bedard, and A. Reed. 1976. Overland migration by Common Eiders of the St. Lawrence estuary. Wilson Bulletin 88: 333-344.

Goudie, R. I., G. J. Robertson, and A. Reed. 2000. Common Eider (Somateria mollissima). No. 546 in The Birds of North America. Edited by A. Poole. Cornell Lab of Ornithology, Ithaca, New York. http://bna.birds.cornell .edu/bna/species/546/articles/introduction. (Accessed on 16 May 2013).

Hicklin, P., and K. Bunker-Popma. 2001. The spring and fall migrations of scoters Melanitta spp., at Confederation Bridge in the Northumberland Strait between New Brunswick and Prince Edward Island. Canadian Field-Naturalist 115: 436-445.

Kahlert, J., A. Leito, B. Laubek, L. Luigujõe, A. Kuresoo, K. Aaen, and A. Luud. 2012. Factors affecting the flight altitude of migrating waterbirds in western Estonia. Ornis Fennica 89: 241-253.

Lock, A. R. 1986. A census of Common Eiders breeding in Labrador and the Maritime provinces. Pages 30-38 in Eider Ducks in Canada. Edited by A. Reed. Canadian Wildlife Service, Report Series No. 47. Canadian Wildlife Service, Environment Canada, Ottawa, Ontario. 177 pages.

MacKinnon, C. M., and A. C. Kennedy. 2006. An observation of the spring 2006 migration of Black Scoter, Melanitta nigra, in Northumberland Strait, interrupted by the Confederation Bridge, New Brunswick-Prince Edward Island. Canadian Field-Naturalist 120: 233-234.

MacKinnon, C. M., and A. C. Kennedy. 2011. Migrant Common Eider, Somateria mollissima, collisions with power transmission lines and shortwave communication towers on the Tantramar Marsh in southeastern New Brunswick. Canadian Field-Naturalist 125: 41-46.

MacKinnon, C. M., R. W. Daury, and R. J. Hicks. 1991. Seabird and seaduck movement through the Northumberland Strait, 1990. Canadian Wildlife Service Technical Report No. 130. Environment Canada, Canadian Wildlife Service - Atlantic Region. 86 pages.

Received 15 November 2012

Accepted 16 May 2013 